\title{
Karakteristik Wisatawan Asia Timur Yang Berkunjung Ke Yogyakarta
}

\author{
Frida Anis Handayani ${ }^{1}$, Ayu Merlita Sari ${ }^{2}$
}

\author{
Affiliation \\ ${ }^{1}$ Applied Bachelor Tour and Travel Business, Vocational Collage Universitas Gadjah Mada \\ ${ }^{2}$ Applied Bachelor Tour and Travel Business, Vocational Collage Universitas Gadjah Mada
}

Correspondence

Frida Anis Handayani Applied Bachelor Tour and Travel Business Vocational Collage

Universitas Gadjah Mada. E-mail: fridaanishandayani@ugm.ac.id

\begin{abstract}
Yogyakarta is not only renowned as the city of education, but also as city of tourism. Now, tourists who visit Yogyakarta are not only dominated by tourists from Europe, but also tourists from East Asia (China, South Korea, and Japan). As known, these three countries have characters who uphold their own culture and hard to accept other people's cultures. However, the increasing number of these tourists indicates that tourist attraction in Yogyakarta has been accepted in East Asia tourist market. By knowing East Asia tourist characteristic, it is expected to be useful to develop tourism in Yogyakarta to attract tourist from East Asia. The data were collected by distributing questionnaires to the Chinese/Korea/Japan-speaking tour guides, interviews, and literature studies. After that, the data were analyzed using qualitative descriptive analysis. The result shows that tourists from East Asia who travel to Yogyakarta are adult and elderly. They are interested in visiting Yogyakarta because of the friendliness of the people and its strong cultural tourism. Many of them visit Yogyakarta on holiday season. They get recommendations from friend's tour agent and travel alone or with family. Tourists are satisfied with the accommodation and facilities provided. However, tourists also submit several complaints, such as expensive entry tickets to destinations, unsuitable local cuisine, minimal clean toilets, and lots of garbage. Broadly speaking, DIY has a great potential to attract foreign tourists from East Asia because of its authentic cultural and natural heritage that cannot be found in their countries.
\end{abstract}

Keywords: tourist characteristics; East Asian tourists; tourism in Yogyakarta.

Article Information:

Submitted 27 Maret 2021|Revised 22 July 2021|Accepted 26 July 2021

Copyright (C) 2021 by the author(s). This article is published by Universitas Gadjah Mada, Indonesia under the Creative Commons Attribution (CC BY 4.0) license. Anyone may reproduce, distribute, translate, and create derivative works of this article (for both commercial and noncommercial purposes), subject to full attribution to the original publication and author(s). The full terms of this license may be seen at http://creativecommons.org/licenses/by/4.0/legalcod 


\section{Pendahuluan}

Sektor kepariwisataan merupakan salah satu sektor terpenting bagi perkembangan Daerah Istimewa Yogyakarta, karena sektor pariwisata mampu meningkatkan perekonomian masyarakat sekitar. Dengan adanya kunjungan wisatawan baik dari dalam maupun luar negeri, tidak hanya akan menambah pendapatan daerah, tetapi juga menghidupkan UMKM dan menambah penghasilan masyarakat sekitar juga tour guide di Yogyakarta. Di Yogyakarta terdapat banyak destinasi wisata yang dapat dinikmati oleh wisatawan, antara lain wisata sejarah, wisata seni, wisata budaya, wisata religi, wisata alam dan lain lain. Belum lagi potensi-potensi wisata alam, wisata budaya dan wisata kuliner yang masih belum dikembangkan dan belum tersentuh oleh pemerintah maupun investor. Dikemudian hari akan semakin banyak bermunculan destinasi wisata yang dapat dinikmati oleh wisatawan sesuai dengan minat dan keinginan saat berkunjung ke Yogyakarta. Dalam mendukung perkembangan pariwisata di Yogyakarta, baik pemerintah propinsi maupun pemerintah daerah telah melakukan banyak hal, antara lain menggali dan membuka tempat-tempat wisata baru, membangun dan memperbaiki fasilitas-fasilitas umum, mendirikan hotel-hotel berbintang, hingga membangun Bandara udara baru internasional yang besar dan megah di kabupaten Kulon Progo. Selain itu, pemerintah juga mendukung perekonomian masyarakat dengan menghidupkan UMKM, serta memberikan pelatihanpelatihan mengenai kepariwisataan. Hal tersebut dilakukan agar dapat menarik lebih banyak wisatawan baik domestik maupun mancanegara untuk berwisata ke Yogyakarta.

Pada tahun 2017 pariwisata di Yogyakarta juga masuk dalam program Wisata Joglosemar, wisata dengan rute Jogja-Solo-Semarang ini ditetapkan sebagai destinasi super prioritas. Ketiga daerah tersebut memiliki destinasi wisata yang banyak dan beranekaragam dan kurang dijamah oleh wisatawan baik wisatawan domestik maupun wisatawan mancanegara, dengan adanya wisata Joglosemar ini diharapkan akan menghidupkan destinasi wisata yang ada di Yogyakarta, Solo dan Semarang dan sekitarnya. Dengan demikian maka destinasi wisata yang terdapat di tiga daerah tersebut akan dikenal oleh wisata domestik maupun wisatawan mancanegara. Hingga saat ini, mayoritas wisatawan Asia Timur yang berkunjung ke Yogyakarta hanya menetap selama dua hari satu malam, sehingga Yogyakarta hanya sebagai daerah transit sebelum atau setelah wistawan berwisata ke daerah lain, sebagai cotoh adalah wisatawan dari China yang berwisata ke Pulau Bali berkunjung sehari ke Yogyakarta untuk mengunjungi Candi Borobudur (Magelang) dan Candi Prambanan terlebih dahulu sebelum bertolak kembali ke China.

Dengan demikian maka para wisatawan tersebut tidak benar-benar menikmati suasana Yogyakarta beserta destinasi wisatanya. Destinasi wisata yang dikunjungi hanya sebatas Candi Prambanan, Candi Borobudur (Jawa Tengah), Keraton dan Malioboro. Untuk destinasi wisata yang ada di kabupaten Gunung Kidul, kabupaten Kulon Progo dan kabupaten Bantul kurang banyak dikunjungi wisatawan Asia Timur, hal ini sangat disayangkan mengingat ketiga kabupaten tersebut juga memiliki potensi wisata alam yang mempesona. Bandara YIA merupakan bandara udara baru yang dibangun di kabupaten Kulon Progo, hal tersebut menambah optimisme masyarakat Kulon Progo dalam memajukan daerahnya masing-masing dengan menggali dan mengembangkan tempat-tempat yang berpotensi sebagai destinasi wisata. Dengan adanya bandara udara internasional di kabupaten Kulon Progo, diharapkan akan dapat menghidupkan 
destinasi wisata yang ada di Kulon Progo dan menjadikan desa-desa di Kulon Progo maju dan unggul dalam bidang pariwisata.

Pada periode tahun 2015 hingga 2019, jumlah wisatawan mancanegara yang berkunjung ke Yogyakarta mengalami pasang surut. Hal tersebut terlihat pada tabel Peringkat Sepuluh Besar Wisatawan Mancanegara yang Berkunjung di DIY yang menggunakan Jasa Akomodasi pada tahun 2015 dan 2019, yang diambil dari Badan Pusat Statistik melalui www.visitingjogja.com.

Table1. Jumlah Kunjungan Wisatawan ke Kulon Progo Tahun 2015 hingga 2019

\begin{tabular}{c|l|l|l|l}
\hline No. & \multicolumn{2}{|c|}{ Tahun 2015} & \multicolumn{2}{c}{ Tahun 2019} \\
\hline & Negara & $\begin{array}{l}\text { Jumlah } \\
\text { wisatawan }\end{array}$ & Negara & $\begin{array}{l}\text { Jumlah } \\
\text { wisatawan }\end{array}$ \\
\hline 1 & Belanda & 33.208 & Malaysia & 51.867 \\
\hline 2. & Jepang & 29.567 & Singapura & 38.169 \\
\hline 3. & Malaysia & 28.059 & Jepang & 37.843 \\
\hline 4. & Perancis & 19.186 & Perancis & 35.794 \\
\hline 5. & Singapura & 18.490 & Belanda & 32.436 \\
\hline 6. & Australia & 16.552 & R.R.China & 22.536 \\
\hline 7 & $\begin{array}{l}\text { Amerika } \\
\text { Serikat }\end{array}$ & 16.401 & Jerman & 19.630 \\
\hline 9 & Jerman & 13.774 & Amerika Serika & 19.732 \\
\hline 10. & R.R.China & 7.702 & Australia & 17.832 \\
\hline
\end{tabular}

Sumber: www.visitingjogja.com

Dari tabel diatas, diketahui bahwa wisatawan yang berasal dari Asia Timur terutama wisatawan China dari tahun 2015 hingga tahun 2019 mengalami kenaikan yang terbilang besar. Demikian juga untuk wisatawan yang berasal dari negara Gingseng (Korea) dan negara Matahari Terbit (Jepang) yang juga mengalami peningkatan. Dapat dimungkinkan dan diharapkan untuk tahuntahun yang akan datang juga akan mengalami kenaikan yang lebih besar, dengan kunjungan destinasi wisata yang lebih beragam. Pada dasarnya Yogyakarta memiliki banyak destinasi wisata yang sesuai dengan minat berwisata orang-orang Asia Timur yang cenderung menyukai wisata alam dan wisata budaya. Letak geografis negara China, Jepang, dan Korea yang sebagian besar merupakan daratan ikut andil dalam mempengaruhi minat dan motivasi masyarakatnya dalam menentukan tujuan wisata, hal tersebut merujuk pada wisata pantai yang tidak begitu banyak ditemui di tiga negara tersebut. Tekanan pekerjaan maupun pendidikan yang tinggi menjadikan penduduknya lebih menyukai wisata alam dan hiburan, dengan alasan bahwa destinasi wisata tersebut dapat menyegarkan kembali pikiran yang penat dengan kesibukan sehari-hari.

Seperti diketahui bahwa masyarakat China, Jepang dan Korea sangat menjunjung tinggi budaya nenek moyang dan masyarakatnya sangat loyal kepada budaya nenek moyang, sehingga ada anggapan bahwa penduduk negara Asia Timur sangat tertutup dan tidak mudah untuk menerima 
kebudayaan dari negara lain. Dengan kunjungan wisatawan dari negara-negara tersebut ke Yogyakarta mengindikasikan bahwa kebudayaan Jawa telah diterima dan masuk dalam pasar wisatawan Asia Timur, wisatawan yang telah merasakan keramahtamahan masyarakat Yogyakarta dalam menerima dan menjamu mereka membuat Yogyakarta sebagai salah satu tempat wisata yang nyaman dan tidak terlupakan. Sehingga wisatawan dari ketiga negara tersebut akan datang kembali ke Yogyakarta untuk kesekian kalinya, tentu saja untuk menikmati destinasi wisata lain yang ada di Yogyakarta.

Dalam sektor pariwisata, Yogyakarta termasuk salah satu propinsi di Indonesia yang memiliki destinasi wisata yang yang beragam yang seharusnya banyak diminati oleh penduduk negara Asia Timur. Destinasi tersebut dibagi menjadi beberapa kategori, antara lain adalah kategori wisata alam, wisata religi, wisata budaya, wisata sejarah, wisata kuliner, dan lain lain. Dalam kurun waktu sepuluh tahun ini, di Yogyakarta telah ditemukan potensi-potensi wisata baru baik di kota maupun di daerah yang kemudian digali dan dikembangkan untuk dijadikan destinasi wisata baru. Pantai-pantai banyak ditemukan kemudian dibuka untuk umum, pedesaan dijadikan sebagai desa wisata, perkampungan dijadikan sebagai kampung wisata, bahkan daerah di sekitar Gunung Merapi telah dijadikan sebagai wisata minat khusus. Dengan destinasi wisata yang beranekaragam tersebut seharusnya mampu menarik lebih banyak wisatawan baik domestik maupun wisatawan asing (terutama wisatawan Asia Timur) untuk berwisata ke Yogyakarta dengan durasi waktu yang lebih lama.

Penelitian yang berjudul "Minat Wisatawan Asia Timur Yang Berkunjung Ke Yogyakarta" yang telah dilakukan oleh penulis terinspirasi oleh meningkatnya kunjungan wisatawan Asia Timur ke Yogyakarta dari tahun 2015-2019. Penelitian tersebut dilakukan untuk mengetahui karakteristik wisatawan Asia Timur (China, Jepang, Korea Selatan), karena karakteristik wisatawan akan mempengaruhi minat kunjungan wisatawan dalam melakukan perjalanan wisata. Hal tersebut dimaksudkan untuk mencari solusi dalam meningkatkan kunjungan wisatawan Asia Timur agar lebih banyak menghabiskan waktu untuk berkunjung ke Yogyakarta, selain itu juga untuk menghidupkan destinasi-destinasi wisata yang ada di propinsi Yogyakarta baik di kabupaten Sleman, Gunung Kidul, Bantul, Kulon Progo dan juga kota Yogyakarta. Dengan demikian diharapkan akan dapat meningkatkan perekonomian masyarakat sekitar obyek wisata, menghidupkan UMKM dan meingkatkan penghasilan para tour guide yang ada di Yogyakarta.

\section{Tinjauan Pustaka}

Menurut Suryadinata (2010:20) metode penelitian merupakan prosedur atau langkah-langkah dalam mendapatkan pengetahuan ilmiah. Prosedur penelitian ini dibagi menjadi tiga tahapan. Tahap pertama, melakukan pengumpulan data. Dalam penelitian ini, teknik pengumpulan data dilakukan dengan menyebarkan kuisioner berisi daftar pertanyaan mengenai karakteristik wisatawan Asia Timur yang berkunjung ke Yogyakarta kepada para narasumber. Narasumber dalam penelitian terbatas pada tour guide yang melayani turis dari negara Jepang, Korea dan Tiongkok sehingga mereka harus fasih dengan ketiga bahasa tersebut. Narasumber yang dipilih merupakan tour guide berlisensi yang tergabung dalam HPI (Himpunan Pramuwisata Indonesia) cabang Yogyakarta. Selain menyebarkan kuisioner, peneliti juga melakukan wawancara kepada 
narasumber. Tahap kedua yaitu melakukan analisis berdasarkan item dalam kuisioner. Tahap terakhir yaitu penyajian data. Data kuisioner dan hasil wawancara yang telah ada tersebut diolah dan dideskripsikan dalam bentuk paragraf.

Salah Wahab (1975:55) mendefinisikan pariwsisata sebagai salah satu jenis industri baru yang mampu mempercepat pertumbuhan ekonomi dan penyediaan lapangan kerja, peningkatan penghasilan, standar hidup serta menstimulasi sektor-sektor produktif lainnya. Selanjutnya, sebagai sektor yang komplek, pariwisata juga merealisasi industri-industri klasik seperti industri kerajinan tangan dan cinderamata, penginapan dan transportasi. Sedangkan menurut H.Kodhyat (1983:4), Pariwisata adalah perjalanan dari satu tempat ke tempat yang lain, bersifat sementara, dilakukan perorangan maupun kelompok, sebagai usaha mencari keseimbangan atau keserasian dan kebahagiaan dengan lingkungan hidup dalam dimensi sosial, budaya, alam, dan ilmu.

Pengertian Minat dalam Kamus Besar Bahasa Indonesia dikemukakan bahwa Minat adalah kecenderungan hati yang tinggi, gairah, keinginan terhadap sesuatu. Sedangkan menurut Crow dan Crow (Ali, 2016), minat dapat dipahami untuk menunjukkan kekuatan motif yang menyebabkan seseorang memberikan perhatian kepada orang, benda, atau aktifitas tertentu. Minat mampu membantu seseorang untuk menentukan keputusan seseorang untuk melaksanakan aktifitas atau tidak. Minat belum dapat diamati secara langsung karena minat merupakan pernyataan psikis, namun dapat diamati dari dinamika atau menifestasi dalam perbuatan atau tingkah laku seseorang. Minat merupakan rasa ketertarikan pada suatu objek karena didasari oleh rasa suka sehingga timbul perhatian yang mengakibatkan ingin terlibat, berhubungan lebih dekat, aktif dan selektif. Minat timbul dan meningkat setelah individu mendapatkan informasi mengenai suatu objek.

Faktor-faktor yang mempengaruhi minat menurut Crow dan Crow adalah:

A. Faktor dorongan atau keinginan dari dalam (inner urges), yaitu keinginan yang berasal dari dalam diri seseorang terhadap sesuatu akan menimbulkan minat tertentu.

B. Faktor motif sosial (social motive), yaitu motif yang berhubungan dengan lingkungan sosial. Seseorang melakukan suatu aktifitas agar dapat diterima dan diakui, di dalamnya termasuk faktor status sosial, harga diri, pestise dan sebagainya.

C. Faktor emosional (emotional motive), yaitu motif yang berkaitan dengan perasaan dan emosi yang berupa dorongan, motif, respon emosional dna pengalaman yang diperoleh individu.

Wisatawan adalah orang yang melakukan perjalanan wisata. Dalam Undang-Undang Republik Indonesia Nomor 10 Tahun 2009 Bab 1 Pasal 1 mengenai Kepariwisataan mendefiniskan wisata sebagai kegiatan perjalanan yang dilakukan oleh sebagian atau sekelompok orang dengan mengunjungi tempat tertentu untuk tujuan rekreasi dan pengembangan diri. Dari beberapa penjelasan diatas dapat disimpulkan bahwa minat wisatawan adalah keinginan atau dorongan yang berasal dari diri sendiri maupun lingkungan sodial untuk melakukan perjalanan wisata untuk mengetahui suatu keunikan di daerah tertentu. Menurut Brida, Disegna, dan Osti (2013) Via Yoga (2018), mengenali kareakter wisatawan akan dapat menggunakan dalam menyasar pasar yang memiliki kesediaan lebih tinggi untuk mengeluarkan uangnya dan menungkatkan kepuasan wisatawan, motivasi, serta keinginan untuk berkunjung kembali ke sebuah destinasi. Setiap 
wisatawan mempunyai karakteristik sangat beragam, tua muda, kaya miskin, asing domestik, berpengalaman atau tidak, semua ingin berwisata dengan keinginan dan harapan yang berbedabeda. Seaton dan Bannet (1996) memberi gambaran mengenai wisatawan berdasarkan karakteristik perjalanannya (trip descriptor) dan karakteristik wisatawannya (tourist descriptor). 1. Trip descriptor, wistawan dibagi ke dalam kelompok berdasarkan jenis perjalanan rekreasi, mengunjungi teman/ keluarga, perjalanan bisnis dan kelompok perjalanan Smith (1989) menambahkan jenis perjalanan untuk kesehatan dan keagamaan.

2. Tourist descriptor, memfokuskan pada wisatawannya, biasanya digambarkan dengan "who wants what, why, when, where and how much?" Karakter ini meliputi karakteristik sosiodemografis, geografis, dan psikografis.

Table2. Gambaran Mengenai Wisatawan Berdasarkan Karakteristik Perjalana dan Wisatawan

\begin{tabular}{l|l}
\hline & Karakteristik \\
\hline & Lama waktu perjalanan \\
\hline Trip descriptor & Jarak yang ditempuh \\
\hline & Waktu perjalanan \\
\hline & Akomodasi yang digunakan \\
\hline & Moda transportasi \\
\hline Tourist descriptor & Teman perjalanan \\
\hline & Pengorganisasian perjalanan \\
\hline & $\begin{array}{l}\text { Karakteristik sosio-demografis (jenis kelamin, } \\
\text { umur, status perkawinan, tingkat pendidikan, } \\
\text { pekerjaan, ukuran keluarga atau jumlah anggota } \\
\text { keluarga, dan lain-lain). }\end{array}$ \\
\hline & Geografis (lokasi tempat asal wisatawan) \\
\hline & Psikografis (sosial, life-style)
\end{tabular}

Sumber: Seaton dan Bannet 1996

Selain itu, penelitian lain yang pernah dilakukan dan mengilhami dilakukan penelitian ini diantaranya adalah sebagai berikut:

Penelitian yang dilakukan oleh Bellinda Sofia Nuraeni (2014) dalam judul tulisannya "Analisis Faktor-faktor yang Mempengaruhi Minat Kunjungan Wisatawan Museum Ranggawarsita Semarang". Penelitian ini membahas mengenai wisatwan yang melakukan kunjungan ulang ke Museum Ranggawarsita, dengan beberapa metode yang telah dilakukan. Penelitian tersebut dapat dijadikan acuan dalam pengembangan wisata herritage yang berupa museum untuk menghasilkan metode daya tarik wisatwan Asia Timur yang berkunjung ke museum yang ada di Yogyakarta.

Pelitian selanjutnya adalah penelitian yang dilakukan oleh Komang Ratih Tanjungsari (2018) yang berjudul "Karakteristik dan Persepsi Wisatawan Macanegara di Kawasan Sanur dan Canggu, Bali". penelitian tersebut bertujuan untuk mengetahui dan menganalisis karakteristik wisatawan mancanegara yang mengunjungi daerah pantai di Bali, khususnya di kawasan panti Sanur dan kawasan Canggu. Kedua kawasan tersebut memiliki karakteristik yang berbeda karena kawasan Sanur memang merupakan kawasan pariwisata sejak awal sejarah pariwisata di Bali, sedangkan kawasan Anggu merupakan kawasan pariwisata yang baru sejak tahun 2000-an dikenal 
wisatawan. Karena perbedaan tersebut, maka terdapat perbedaan hasil di beberapa karakteristik, seperti asal negara dan tipe tempat tinggal wisatawan tersebut. Penelitian tersebut dapat dijadikan patokan dalam studi kasus untuk mendapatkan karakteristik wisaatawan dari China, Jepang dan Korea yang pada umumnya memiliki latar belakang sifat, sikap dan minat kunjungan yang hampir sama.

\section{Metode Penulisan}

Dalam menulis artikel yang berjudul "Karakter Wisatawan Asia Timur Yan Berkunjung Ke Yogyakarta" ini, penulis menggunakan metode kualitatif yaitu dengan melakukan wawancara dan studi pustaka. Artikel ini merupakan hasil dari penelitian yang penulis lakukan di tahun 2020 yang berjudul "Minat Wisatawan Asia Timur Yang Berkunjung Ke Yogyakarta". Penelitian tersebut dilakukan dengan metode kuantitatif dan kualitatif, dikarenakan pada tahun 2020 terdapat pandemi Covid-19, oleh karenanya penelitian dilakukan secara virtual. Menurut Suryana (2010:20) metode penelitian merupakan prosedur atau langkah-langkah dalam mendapatkan pengetahuan ilmiah. Prosedur penelitian ini dibagi menjadi 3 (tiga) tahapan. Tahap pertama, melakukan pengumpulan data. Teknik pengumpulan data dilakukan dengan menyebarkan kuisioner berisi daftar pertanyaan mengenai karakteristik wisatawan Asia Timur yang berkunjung ke Yogyakarta kepada narasumber. Narasumber dalam penelitian ini terbatas pada pemandu wisata yang melayani turis dari negara China, Jepang dan Korea sehingga mereka pun fasih dengan ketiga bahasa tersebut. Narasumber yang dipilih merupakan pemandu wisata yang bekerja untuk agen perjalanan wisata maupun secara pribadi dan telah memiliki pengalaman menjadu pemandu wisata lebih dari dua tahun. Selain menyebarkan kuisioner, peneliti juga melakukan wawancara kepada narasumber. Tahap kedua adalah melakukan analisis berdasarkan item dalam kuisioner. Tahap ketiga atau terakhir adalah menyajikan data. Data-data kuisioner yang didapat tersebut diolah dan dideskripsikan dengan baik dalam bentuk paragraf.

\section{Hasil dan Pembahasan}

Mengenal dan memahami karakteristik wisatawan akan bermanfaat dalam menyasar pasar yang memiliki kesediaan lebih tinggi untuk mengeluarkan uang dan meningkatkan kepuasan wisatawan, motivasi, serta keinginan untuk berkunjung kembali ke sebuah destinasi. Setiap wisatawan mempunyai karakteristik sangat beragam, dapat disimpulkan berdasarkan; tua muda, kaya miskin, asing domestik, berpengalaman atau tidak, semua ingin berwisata dengan keinginan dan harapan yang berbeda-beda.

Lee (2011) mendeskripsikan karakter orang Jepang sebagai pribadi yang cenderung kalem, sopan, perencana yang baik, sedangkan orang Korea lebih agresif, enerjik dan dimanis. Karakteristik seperti ini menurut Oh Kong-Dan seorang ahli wisatawan Asia Timur yang berbasis di Washington (via Lee) dapat terjadi karena dipengaruhi oleh lingkungan geografis, makanan, dan tingkat pendidikan. Sedangkan untuk karakteristik wisatawan dari China cenderung lebih antusias, hal tersebut dapat dilihat dari wisatawan lansia yang berkunjung ke Candi Borobudur (Jawa Tengah), meskipun telah lanjut usia akan tetapi mereka sangat antusias untuk menaiki tangga-tangga Candi Borobudur. Mengenai wisatawan China dalam berkunjung ke Indonesia dijelaskan dalam (Rosyidi, 2018,pp.145-158) bahwa wisatawan dari China lebih memilih tour guide dan staf hotel 
yang bisa berbahasa Mandarin, fasilitas pembayaran dengan non tunai seperti UnionPay atau pembayaran via Wechat (platform pembayaran di China), dan TV channels yang menayangkan program dari negara China .

Berdasarkan hasil penelitian, karakteristik wisatawan yang melakukan perjalanan ke Yogyakarta adalah sebagai berikut:

1. Karakteristik Wisatawan Berdasarkan Usia

Wisatawan Asia Timur (China, Jepang, Korea Selatan) yang mengunjungi Yogyakarta dengan meggunakan jasa pemandu wisata memiliki rentang usia dewasa dan lansia. Rentang usia dewasa menurut pembagian WHO adalah rentang usia 26-45 tahun, sedangkan kategori lansia adalah mereka yang berusia diatas 46-65 tahun. Wisatawan berusia remaja (12-25 tahun) yang umumnya adalah pelajar atau mahasiswa umumnya melakukan perjalanan dengan membuat itinerary sendiri tanpa menggunakan bantuan jasa dari agen perjalanan wisata, sehingga tidak termasuk dalam hasil penelitian ini.

2. Karakteristik wisatawan berdasarkan jumlah

Wisatawan Asia Timur melakukan perjalanan wisata ke Yogyakarta secara berkelompok dalam satu keluarga (50\%), rombongan tur (40\%), dan solo traveller (10\%). Rombongan tur ini berisi teman sekantor, rekan bisnis, maupun rombongan-rombongan wisata kecil lainnya. Sementara itu, solo traveller dalam penelitian ini merupakan pelancong yang memang khusus melakukan perjalanan dengan konsep private tour dengan paket wisata yang diatur berdasarkan permintan dari wisatawan.

3. Karakteristik wisatawan berdasarkan waktu dan lama berkunjung

Musim liburan atau liburan musim panas dan musim dingin masih menjadi favorit para wisatawan Asia Timur untuk berwisata ke Yogyakarta. Mereka datang pada saat high season yang bertepatan dengan liburan sekolah dan peak season yang jatuh pada pertengahan bulan Desember hingga bulan Januari. Lama berkunjung wisatawan adalah dua hari satu malam (1N2D) dan dua malam tiga hari (2N3D).

4. Obyek wisata favorit wisatawan Asia Timur

Obyek wisata favorit wisatawan Asia Timur ketika berkunjung ke Yogyakarta adalah Candi Prambanan dan Candi Borobudur (Jawa Tengah), Keraton Yogyakarta dan Malioboro. Wisatawan dari ketiga negara tersebut sangat terkesan ketika mengunjungi kedua candi tersebut karena memiliki arsitektur yang megah, juga memiliki cerita yang indah dibalik kemegahan bangunannya. Rute perjalanan tersebut sesuai dengan paket wisata yang ditawarkan oleh agen perjalanan wisata. Sejak tahun 2015 wisata adventure di Kabupaten Gunung Kidul (Gua Pindul dan pantai), Kabupaten Bantul (Hutan Pinus) dan Kabupaten Sleman (Lava Tour) mulai dikunjungi oleh wisatawan remaja dari negara Tiongkok.

5. Tanggapan wisatawan terkait akomodasi dan fasilitas

Wisatawan Asia Timur lebih suka tinggal di hotel bintang 4/5. Data statistik DIY tahun 2019 menyebutkan bahwa wisatawan dari Jepang, Korea Selatan dan Tiongkok menduduki peringkat 10 besar sebagai wisatawan mancanegara yang menggunakan akomodasi hotel bintang dan non bintang. Wisatawan Asia Timur mudah dalam mendapatkan informasi tentang obyek wisata, akan tetapi sebagian informasi hanya tersedia dalam bahasa Inggris, tidak dalam bahasa lokal (bahasa Jepang, bahasa Korea dan bahasa Mandarin). Selama ini, tour guide tidak banyak mendapat keluhan terkait akomodasi dan fasilitas. Masalah yang 
pernah muncul diantaranya adalah, perbedaan stop kontak atau colokan listrik di Indonesia dan negara asal, dan masih ada sampah yang berserakan di tempaat wisata meskipun sudah banyak tersedia tempat sampah.

6. Karakterstik wisatawan terhadap makanan lokal

Sebagian wisatawan Asia Timur mengatakan kurang begitu cocok dengan masakan lokal karena rasanya manis. Oleh karena itu, pihak agen perjalanan wisata selalu menyediakan paket makanan di restoran China, Jepang dan Korea.

7. Karakteristik wisatawan tentang berbelanja produk lokal

Baik wisatawan Jepang, Korea Selatan maupun Tiongkok ada yang menyukai belanja dan ada yang tidak. Wisatawan Korea yang tidak menyukai belanja beralasan bahwa harga barang yang dijual di toko yang direkomendasikan agen perjalanan wisata lebih mahal dan wisatawan merasa tidak nyaman jika diajak ke toko yang direkomendasikan oleh agen perjalanan wisata. Untuk mengantisipasi hal tersebut, di setiap paket wisata yang ditawarkan kepada wisatawan Korea Selatan seringkali diberi keterangan no option no shopping. Bagi wisatawan yang senang berbelanja, mereka tidak memperdulikan barang tersebut bermerk atau tidak, juga tidak mempermasalahkan kualitas sebuah barang. Akan tetapi, wisatawan yang berkunjung umumnya mempunyai jadwal ke destinasi lain di Indonesia, sehingga mereka mempertimbangkan supaya tidak over bagasi.

\section{Kesimpulan}

Wisatawan Asia Timur memiliki karakteristik yang unik, secara umum karakter tersebut mengarah sifat nasionalis wisatawan kepada negara asal. Hal tersebut dapat terlihat dari minat dan cara wisatawan menikmati suatu destinasi wisata, cara berbelanja, juga dalam mencari tour guide. Wisatawan dari Asia Timur dalam berwisata sangat mementingkan bahasa dalam berkomunikasi, sehingga mereka cenderung memilih tour guide yang mampu berbahasa China, Jepang maupun Korea. Dengan tour guide yang memiliki keahlian dalam berbicara bahasa China, Jepang dan Korea, maka wisatawan akan bisa menikmati destinasi wisata yang ditawarkan. Wisatawan Asia Timur (China, Jepang dan Korea Selatan) yang berkunjung ke Yogyakarta tertarik akan wisata alam dan wisata budaya yang ada di Yogyakarta. Wisatawan Asia Timur menunjukkan respon dan kesan positif setelah berkunjung ke Yogyakarta. Hal positif yang wisatawan rasakan antara lain, wisatawan dapat menikmati suasana masa lampau, mayarakat kota Yogyakarta masih kental dengan budaya Jawa dan ramah senyum kepada warga asing, sehingga wisatawan merasa aman dan nyaman untuk berwisata.

Meski demikian, wisatawan juga menyampaikan beberapa keluhan, tiket masuk destinasi wisata yang terbilang mahal, masakan lokal yang kurang cocok dengan lidah wisatawan, kebersihan di beberapa destinasi wisata yang kurang terjaga, dan tidak adanya informasi wisata berbahasa Jepang, Korea dan Mandarin. Secara garis besar, propinsi DIY berpotensi besar menarik wisatawan dari Asia Timur. Dengan beragamnya destinasi wisata yang ada di Yogyakarta seharusnya dapat menyasar wisatawan dari segala usia. Pengelolaan destinasi wisata yang baik dan ramah turis, akses transportasi yang baik, akan menjadi poin tersendiri untuk memotivasi kunjungan wisatawan. Ditambah lagi dengan digencarkannya promosi destinasi wisata baik via media sosial maupun pameran pariwisata di Yogyakarta dalam bahasa Mandarin, bahasa Jepang 
dan bahasa Korea, maka diharapkan wisatawan yang datang berkunjung juga akan semakin banyak.

\section{Daftar Pustaka}

Ali, Bagina Syah, 2016, Strategi Pengembangan Fasilitas Guna Meningkatkan Daya Tarik Minat Wisatawan di Darajat Pass (Waterpark). Kecamatan Pasirwangi Kabupaten Garut, Bandung: UPI

Biro Pusat Statistik, 2018, Pariwisata DIY: Statistik Kepariwisataan

Nuraeni, Bellinda Sofia, 2014, Analisis Faktor-faktor yang Mempengaruhi Minat Kunjungan Wistawan Museum Ranggawarsita Semarang. Jurnal Bisnis Strategi Vol.23. No.1 Juli, Hal 1-20 Ramadhan, Abdurrahman Hikmah, Suryono, dkk 2015. Pengaruh City Branding Terhadap Minat Berkunjung Serta Dampaknya Pada Keputusan Berkunjung. Jurnal Administrasi Bisnis, Vol.28, No.1 November 2015. Hal 1-7

Rosyidi, M.I 2018, The Caracteristics of Chinese Tourisr in Indonesia and its Performance in 20132017. Binus Business Review, Vol 9 No.2, Hal 145-152

Suryana, Abdurrahman Hikmah, Suryono dkk, 2015, Pengaruh City Branding Terhadap Minat Berkunjung Wisatawan Museum Ranggawarsita Semarang, Jurnal bisinis Strategi Vol.23 No.1 November 2015, Hal 1-7

Tanjungsari, Komang Ratih.2018. Karakteristik dan Persepsi Wisatawan Mancanegara di Kawasan Sanur dan Canggu, Bali. Jurnal Pariwisata Terapan, No.2, Vol.2, Hal 108-121

Yoga, I Made Sindhu, Putu Ratna Juwisata dkk, 2018, Clustering Rata-rata Tingkat Spending Money Berdasarkan Profil Geografis dan Preferensi Konsumsi Wisatawan Mncanegara di Kota Denpasar, Jurnal Imiah Manajemen \& Bisnis, No.1, Vol.3, Hal 47-48

Cnbc Indonesia. Diakses pada tanggal 18 Oktober 2020, http://www.cnbcindonesia.com/market/awas-risiko-mengintai-pertumbuhan-ekonomi-asiatimur

The Korean Times. Diakses tanggal 19 Oktober 2020, http://www.koreantimes.co.kr/www/news/opinon Travel Detik.com, diakses tanggal 19 Oktober 2020, https://travel.detik.com/travel-news/d-3700434/wisata-joglosemar-liburan-komplet-di-jawa http://id.wikipedia.org/wiki/Agama_di_Korea_Selatan http://id.wikipedia.org/wiki/Agama_di_Jepang http://www.berpendidikan.com/2019/07/sejarah-perkembangan-agama-buddha-di-asia-timur http://m.republika.co.id/berita/gaya-hidup/travelling/19/08/29/pwzotj463-joglosemarpariwisata-super-prioritas-yang-terintegrasi http://visitingjogja.com diakses pada tanggal 18 Oktober 2020 